$\frac{\text { Security }}{323.26: 328.16(497.7) " 2014 / 2015 "}$

\title{
SOCIAL MOVEMENTS AND PROTESTS IN MACEDONIA: BETWEEN STATE-BUILDING AND POPULAR DEMANDS FROM BELOW
}

\author{
Biljana Vankovska
}

\begin{abstract}
The paper focuses on the legitimacy crisis in Macedonia through the prism of two contradictory tendencies: on one hand, for years international state-building has had democratic institution-building as priority rather than building capacities for democratic policies; on the other hand, the upsurge of social movements and protests in 2014-2015 questioned not only the legitimacy on those on power but also demanded radical shift of the political and social agenda. The protracted political crisis (2012-2015) has demonstrated the contradictory nature of the top-bottom and bottom-up political tendencies. The system that had been set up through exclusive input of the political elites under the auspices of the international community is now challenged by new participatory political forms of citizens' engagement. The key question set in this paper reads: is Macedonian Spring possible under the constraints of the international state-building and what effect would one expect from such a political turnabout?
\end{abstract}

Key words: social movements, protests, political parties, international statebuilding, the Republic of Macedonia

\section{Introduction: the Global Context}

The institutional design of modern democracies embodies ideas from different political philosophies. Each of the major traditions gives a different weighting to equal liberties for everybody, democratic participation, and government by public opinion. The liberal tradition reveals a preference for the liberties of private citizens, whereas republican and deliberative traditions stress either the political participation of active citizens or the formation of considered public opinions (Habermas 1998). Democratic citizenship, that is, the inclusion of free and equal citizens in the political community is to guarantee the 
political participation of as many interested citizens as possible through equal communication and participation rights; periodic elections (and referendums) on the basis of an inclusive suffrage; the competition between different parties, platforms, and programs; and the majority principle for political decisions in representative bodies. (Habermas, 2006: 412). The different weighting that citizens of different nations assign to rights and liberties, to inclusion and equality, or to public deliberation and problem solving determines how they see themselves as members of their political community.

However, in time of crisis, students of democracy are enforced to confront and delineate what "ought to be" vs. the sobering "what really is". Opposite to the conventional wisdom about democracy as a "rule of the people", another paradigm has become dominant in many Western states. "Democracy without people" presumes that as long as the democratically elected elites are doing their job well, the citizens may afford being politically passive. Thus activism (except in a form of charity) was perceived as neither indispensable nor desirable. The electoral democracy has been praised as an ultimate act of expression of citizens' will; the other political rights has always had only complementary and instrumental role for the sake of representative democracy. The ongoing crisis of democracy is but the other side of the coin of the predominant crisis of capitalism. Apart from critical scholars and dissidents, occasionally there are distinguished ex-politicians such as the former US president Jimmy Carter ${ }^{1}$ - who speak of oligarchy as a form of government and accumulation of wealth in the hands of few that has direct impact on the political sphere. The members of the political class become entrepreneurs and representatives of the capital rather than of the citizens. Decision-making process is determined by the market forces and interests - thus the legal order is subdued to the predominant interests of those on power. Elections become meaningless since the voters are practically able to choose between Coke and Pepsi, i.e. between two fractions of a same liberal party. Chantal Mouffe (2015) rightly points out that this in turn leads to the depoliticisation of people and a lack of interest in what is going on in our societies. ${ }^{2}$ Jacques

\footnotetext{
${ }^{1}$ Jimmy Carter's statement is available at: https://www.youtube.com/watch?v=hDsPWmioSHg (accessed on 10 October 2015)

${ }^{2}$ Chantal Mouffe, "Transforming Political Consciousness", Green European Project, July 2015, available at: $\quad$ http://www.greeneuropeanjournal.eu/wp-content/uploads/2015/09/GEF-ED-2015-web.pdf (accessed on 11 October 2015)
} 
Ranciere (2015) agrees that there is growing feeling of fatality: people vote for their own oligarchs due to the belief that it could have been worse without them. ${ }^{3}$

The idea that there is a strong connection between capitalism and democracy has become a dogma translated into the theory of liberal peace. It appears in two divergent versions: the conviction that there is a natural link between capitalism and democracy, on the one hand, and the conviction that these two phenomena are naturally in tension with each other, on the other hand (Wagner 2011). The democratic nation-state has lost its regulatory power as soon as the economic and financial power has definitively crossed its boundaries. The critical philosophers agree that capitalist economy formed the basic structure of Western societies, but conceive democracy as nothing but a 'surface phenomenon' (Adorno quoted by Wagner 2012). The history shows that co-existence of capitalism and democracy is viable but also that in democracy tends to be abandoned to safeguard the interests of capital when necessary. High-intensity democracy - inclusive and with high levels of deliberation and participation - stands in a principled tension with capitalism because the mass participation may challenge the foundations of capitalist system as such. The paradigm of lazy, sleepy and content citizens does not work anymore even in the most developed countries - the people have awakened due to the deep social crisis. The mainstream politics has alienated itself from society it is supposed to represent and govern. As a reaction, mass grass-root movements set their own agenda and different political methods that are in opposite to the state one. Social movements and mass protests become a significant if not dominant form of expression of the people's grievances over growing social inequality and political marginalization. Puhovski (2014) rightly points out is a paradox: routinized "single issue" protests, which are typical for democratic functioning of any polity, do not question legitimacy of power; unlike them, the protests that are directed towards change of government by default focus precisely on the legitimacy issue. So far, the usual pattern of delegitimation of incumbent government has been summarized in the parole "Down with the non-popular (undemocratic) government!". The civil society activists and movements in some socialist countries took the streets with one major demand: free and democratic elections that would bring political change and install democratic order. The slogans and demands of the protesters in the so-called Arab

\footnotetext{
${ }^{3}$ Jacques Ranciere, "Sistem djeluje izazivajući osjećaj nemoći kod ljudi", Tačno. net, 16 October 2015, available at: http://www.tacno.net/interview/intervju-jacques-ranciere-filozof-sistem-djelujeizazivajuci-osjecaj-nemoci-kod-ljudi/ (accessed on 20 October 2015)
} 
Spring were the same. Although similar at glance, the mass protests in democratic societies and those in non-democratic ones differ a lot in terms of the goals and visions. The movements in the authoritarian systems call for introduction of liberal democracy, while the protesters and activists in the West rise against that very system that have disappointed and betrayed them for generations. The radical protests in the democracies are paradoxical because the anger is directed against those that were elected by majority will of the demos itself: people protest against demos (Puhovski 2014).

\section{Parties, Movements and NGOs in Times of Cholera}

Despite their apparently long history, defining social movements is not an easy task. Although authors may agree that the movements are all about interactions with the state (or better, with power structures) there are big differences with regard to their situating within the political system. Some speak of challenging groups (Tilly 1984), so social movements are seen as "challengers" that seek to enter the institutionalized world of "polity members" who have routinized access to the levers of power. Gamson (1990) depicts social movements as "outsider groups" whose challenges succeed for such groups become recognized actors in institutional politics. If social movements truly become acknowledged partners in the institutionalized politics it is expected that they demobilize afterwards; in other words, they are seen as necessarily extrainstitutional. Jenkins and Kaldermans (1995, p. 3) argue that social movements constitute a potential rival to the political representation system and can play a major role in restructuring the relationship between the state and civil society. By speaking of social protest, they point to the collective action of social movements that are attempting to alter the representation system, public policies, or the general relationships between citizens and the state.

Goldstone (2003) criticizes the persistent tendency to see this interaction as distinct from normal politics. He defines the interaction between state and social movements in a different way: movements constitute an essential element of normal politics in modern societies, and there is only a fuzzy and permeable boundary between institutionalized and noninstitutionalized politics. Accordingly, one cannot understand the normal, institutionalized workings of courts, legislatures, executives, or parties without understanding their intimate and ongoing shaping by social movements. Indeed, state institutions and parties are interpenetrated by social movements, often developing out of movements, in response to movements, or in close association with movements. Meyer and Tarrow (1998) claim that Western democracies are becoming "movement societies,"; 
movements have become so routine, so institutionalized (through permits for demonstrations and referendums by petition) that they are now part of normal politics. Yet Coldstone makes a step further claiming that social movements are not merely another forum for or method of routinized political expression, but they have rather become part of the environment and social structures that shape and give rise to parties, courts, legislatures, and elections. While this standpoint tries to bridge institutionalized and noninstitutionalized politics (unlike the first one that confronts them), there is also a third possible explanation: the social movements could be either sign of institutional failure of representative democracy (in times when capitalism divorces itself from democratic institutions and principles) or they may be just a form in which mainstream political subjects re-brand themselves as social movements in order to regain their lost legitimacy.

Studies of social movements and of political parties have usually treated them as separate and distinct. In fact, they are deeply intertwined. Social movements often shape electoral competition and party policies; they can even give rise to new parties. The best examples for the former are Syriza victory in Greece and the re-birth of the Labour Party in UK during the election of the party leader in 2015. The most illustrative example of a new party born out of a protest movement is Podemos in Spain. These examples actually offer a new perspective of the ways in which horizontality of a mass movement may combine with the verticality of party organization in order to bring changes through the electoral process.

\section{Do Protests Have any Meaning under State-Building Process?}

For a short period of time (October 2014-mid July 2015) it looked as if the Macedonian citizens had joined global trends when it comes to citizens' protests and activism. In October 2014, it was the surge of a new student movement (Student Plenum) that raised optimism about the political awakening of otherwise apathetic society. In spite of the rather modest demands (related to the higher education and student standard), the student activists send a clear and loud message chanting: "This is just a beginning!" As soon as the protests mobilized a surprisingly big number of citizens from all walks of life, some started enthusiastically talking of "Spring in December" (referring to a song of popular YU-group "Azra"). Within a fortnight, various plenums mushroomed in different spheres: the society embraced a form of horizontal self-organization. So-called plenumisation took place among high school students, teachers, parents, and even journalists. There was even an ambition to create a general "umbrella plenum" - a Citizen's plenum - that would articulate grievances of the numerous interest groups. The process coincided with a major political 
crisis related to wire-tapping scandal and the release of so-called "political bombshells" by the major opposition party. By May 2015 there was an impression that Macedonia was on a brink of the Political New, i.e. that the energy that engulfed the society had unifying force and power to change the foundations of the political state. However after the peak (the impressive mass rally of 17 May) things gradually turned into a downfall. By the midsummer, the Macedonian Spring has proved to be just a pipe-dream. Thus the central issue is if the protest movements have had any success, or better - have they become an indicator for a radical change in the political system or a symptom of a system failure as such.

In order to come to some tentative conclusions (especially as these are recent phenomena and the political crisis is ongoing), one should pay attention to the specific national context and the dominant political culture as determinants of the future developments. Democratic transition in Macedonia came as a surprise: practically there was no civil society to demand democratization and liberalization, but the new constitutional order was established upon gaining independence in 1991. It was inevitably accompanied by a swift primitive accumulation of capital. The criminal privatization gave birth to new capitalist class and created a lasting ground for the new ruling elites. The raising inequality gap was just a consequence of the empty democratic shell that provided facade for the crony capitalism. The narrative of independent statehood served as a sugar-coated pill for all those who were pushed in the grey zone of pauperization. They put quasi-ideological coats in order to play the democratic game of pluralism and parliamentarism. On the other hand, there was no resistance to any step in the establishment of any new distribution of social resources and the new power structures - the population was happy that there was no war like elsewhere in the neighbourhood.

The pact among the political, business and media elites has been working perfectly ever since. The political pluralism was soon exhausted as an idea(I) and the party landscape simplified especially since 2001: once divided along ethnic lines, the two major ethnic communities practically formed bi-party system each. Once in a governing coalition the major Macedonian and the Albanian parties would cooperate very well, especially in terms of sharing the electoral spoils. Having been unable to deliver any of the promises to their voters, the parties often play the nationalist card. Having embraced roughly identical neoliberal positions the political parties have become all-catch parties by default. One ideology (communist) was declared dead and instead replaced by another (neoliberal) that has become secular religion. 
The 2001 ethnic conflict was short-lived. Again Macedonia became an international success story, and since then - an object of an intensive international state-building. The international mediators accepted fait accompli on the ground i.e. alleged impossibility of living together unless there are special rules of the game in a form of power-sharing (Vankovska 2014). The Macedonians and Albanians have always been living in parallel worlds but ethnic differences were now constitutionalized and became a bargaining chip in the political game. The cartel of ethnic elites, decision-making based on double-majority rule and the quota system of recruitment of officials and administrative staff only deepened already persistent partitocracy (Siljanovska-Davkova 2005, 2014).

Introduction of the power-sharing system as a follow up of the 2001 Framework Agreement meant implicit abandonment of the liberal model of parliamentarism. The hybrid ethno-illiberal system ever since suffers deadlocks due to the perpetual ethnic bargaining within the governing coalition but also due to the protest and boycott tactics of otherwise impotent opposition. The negotiation process is regularly facilitated by the EU and the US ambassadors or other international officials. The international community has become a direct and powerful actor in the political process. Instead of institution-building and democracy learning process, the outcome is the opposite: not only the political elites but the public as well develops dependency syndrome. The state-building process enforces the state weakness instead of empowering the institutions and the democratic policy. To paraphrase Chandler (2006, p. 30), non-Western states, particularly those in the Balkans, are more accountable to international-policy makers than to their own people. Except during the elections, the citizens have been forgotten by all parties i.e. instead of being active participants in the political process they have become voters in elections that do not resolve or change anything. The rule of the conservative VMRO-DPMNE (especially since 2008 elections) introduced a rather different approach by using extrainstitutional mechanisms for gaining support - 'spontaneous' mass gatherings in support of the government or counter-protests against the opposition. Only at the beginning of the political crisis (2012-2015) the opposition started using populist rhetoric in Ernesto Laclau's terms (2005), trying to speak on behalf of "we, the people". Yet it is not sure if the Macedonian public, and especially the activists and intellectuals, have become aware that all sides - both political parties and non-party actors - were in fact trying to construct the political through populist means.

Usually, each ethnic block witnesses internal political strive in a rather confrontational, exclusivist and antagonistic manner. A major empirical analysis (Hristova et 
al. 2011, p. 236) concludes the following: "The political conflict based on the idea Traitors Patriots pushed the citizens of Macedonia into one continuous political battle in which one Macedonia needed to conquer some other Macedonia - completely...." The Albanian parties follow the same pattern despite the slightly different rhetoric. The politics has become a continuation of war with different means as it is a matter of "live and death" rather than a struggle for leading governing positions and good governance. The militarized politics divert the majority citizens who have had enough from each of the two major political options. The absentees have grown in a major (but still unconscious) political group in Macedonia on both sides of the political and ethnic divide.

\section{Active Citizenship and Protests: The Uncharted Territory}

The story of active citizenship and participation in Macedonia is quite a short one. The conventional wisdom says that civic resistance to authoritarian policies or even the mere participation in the public affairs is something not very emblematical for the Macedonian population. As it happens, Macedonia does not differ a lot in this respect from the other post-socialist and post-conflict states. The 1991 Constitution guarantees a long list of political rights and freedoms. Yet their utilization has been modest: the while one could hardly talk about any meaningful and even less organized struggle or protest for their defence. The episodes of direct participation of citizens in the political process, by default, show that it has never been very popular with the political elites - and rarely encouraged or tolerated. After the initial enthusiasm politics has become something to be disgusted of, or at best - to profit from personally (by getting a party membership card). Petitions and national-wide initiatives focused mostly on political and/or ethnic issues. The social and economic demands have been neglected due to the naive conviction that the problems arise from the inconsistent functioning of the otherwise ideal political system; thus, the origin of the problem was in the personalities/ politicians rather than in the framework that allowed such political domination based on clientelism, soft coercion and corruption.

\section{The Macedonian Melancholic Revolution}

Growing discontent has never been a secret but it was hardly articulated, well organized or consistent. Eventually, protests have become more frequent and diverse. The inflation of various protests and other forms of activism has its other side: the protests would usually bring together the same flock of people, mostly intellectuals and/or NGO 
activists. The silent majority has remained passive observer despite the dissatisfaction. The same persons would promote various agendas and speak up on behalf of wider groups. They are usually well-trained, wells-spoken and financially supported with foreign grants. Such protests have either been seen as ill-attended or just as a mere spectacle with no content (or even genuine conviction).

In addition to the dominant passivity, the reasons for the limited effects of the public protests should be sought in some other aspects of the political life. Having been coping with its growing irrelevance and impotence, the opposition transforms itself into a non-governmental entity. It happened more than once that the leading politicians from the opposition take the first rows in rather authentic protests of various societal groups. As a response, the ruling VMRO-DPMNE has invented so-called counter-protests; its own party activists would put the hats of ordinary citizens who support governmental policies. The 2014 survey results show that as many as 73.4\% of the respondents does not believe in spontaneity of the protests. The political parties have usurped the space and the forms of civic engagement. The NGO sector is being divided along political lines too, so each political party could rely on its 'own people'. The underlying reason for this is to be found in the systemic disempowerment of the people.

The most surprising but also the most promising protest that Macedonia has witnessed in its 25 years long independence were the student protests in 2014/2015. The campaign started shyly and swiftly grew into a mass movement. The public euphoria grew and the public called upon the students to take over the state leadership. Few believed that it was all only about student/educational matters - those on power out of fear, while the others out of hope. At first the ruling elite ignored the student demands as well as the protests. Nevertheless, as soon as they became impossible to ignore, another tactics was employed: it was said that the students were manipulated by the opposition or even declared provocateurs financed by external powers in order to incite a Macedonian Euromaidan. It was exactly Student Plenum's distance from the party life that attracted the citizens and gained them such a great admiration. A number of university professors followed the students' example and formed Professor Plenum.

The political crisis that deepened due to the wire-tapping scandal escalated on 5th May 2015. After months of peaceful protests, this was the first one to end in violence. It was a turning point: the political reason overshadowed all the others. It created a scene for Manichean battle between Good and Evil. As a consequence, the protesters organized a group "I protest for peace and justice" (\#Protestiram). According to the public 
announcement, "in a citizen plenum, those present at the gathering reformulated the goals of the protests. \#Протестирам (\#Protestiram), a broad citizens' movement was established, fusion of previous movements and initiatives. Their demands are: urgent resignation and responsibility from the Government; 2 ) urgent release of all activists detained since May 5 , 2015 and 3) formation of Government to democratize state institutions. ${ }^{4}$ The students joined this new form of activism claiming that it was impossible and even immoral to negotiate with an authoritarian regime.

The opposition had a similar scenario and formed another movement: "Citizens for Macedonia" brought together a long list of well-established NGOs as well as activists and intellectuals. A mass rally under the slogan "We are coming" took place on 17 May in front of the government. At the end of the day, the protesters set up a "Freedom Camp": a number of tents remained in front of the government till the end of the already ongoing political negotiations between the ruling and opposition parties under the auspices of the international community. Eventually, everything turned into a big spectacle: the 'citizens' were partying during the warm summer nights, and the revolution ended up in a karaokeshow where the protesters were singing "The government is falling".

Apart from the fact that VMRO-DPMNE remained loyal to its habits and organized equally big gathering the following day (including a counter camp in front of the parliament building), more interesting and far more significant was the interplay within the opposition block. While the political opposition was trying to present itself as a nation-wide movement against the government, the smaller new movements were trying to distance themselves from it. ${ }^{5}$ Later on, another activist of \#Protestiram concluded that "after After May 17th, the resistance entered in a deep crisis. The protests deflated and the awaited turnaround did not happen" (Sisovski 2015). From that moment on, \#Protestiram had been trying to revive the politics of passion and to mobilize more people on the streets but in vain. The

\footnotetext{
${ }^{4}$ See more: http://protestiram.info/?page_id=40 (accessed on 10 October 2015).

${ }^{5}$ In a TV debate Stefan Vidikov put it explicitly that the Student Plenum voted for their presence at the 17 May rally but with a distinction that it was not a part of the "Citizens for Macedonia" or any opposition party, but that they all had common interest:

http://novatv.mk/index.php?navig=8\&cat=27\&vest $=22428$ (accessed on 10 0ctober 2015). In a FB post, one of the most active members of \#Protestiram, Anastas Vangeli, wrote that the actions of opposition and its coalition of parties and NGOs was suffocating pluralism among the resistance forces.
} 
high politics got priority especially in the classical negotiation process where the international state-builders preferred to deal with the party leaders.

The inter-party negotiations (and eventually the phase of the implementation of the so-called Przino Agreement) clarified the differences between the two resistance blocks. The Social Democrats' critique was directed towards its political opponent but not against the system, while \#Protestiram wanted a radical political and social change (it however remained short of any more specific vision, strategy or tactics; the international mediators felt much more comfortable with the politicians they could control - the new ideas that may have resembled a 'Macedonian Syriza/Podemos' were suspicious and unpredictable. The political solution of the crisis, according to the activists of \#Protestiram, was not only painful to follow but even something that had exterminated the very idea of protests and resistance (Vangeli 2015). However, a self-critical activist (Sisovski 2015) claims that the movement was ideologically incoherent body, and the main bone of contest was how close or far the activist were from the social democrats' positions: "The main disadvantage of the movement was in the fundamental unsustainability of the idea of burying all differences until the fall of the regime. It became evident that the differences were substantial and ideological. While some showed strong liberal and anti-authoritarian tendencies, the proSDSM group acted in quite an authoritarian fashion. The constant insistence on a complete and blind support of the SDSM leadership, the 'you are either with us or against us' logic, and the demonization of everyone who did not give their wholehearted support to SDSM with the derogatory "neutrals" only went to show the authoritarian tendencies in the ranks of the pro-SDSM wing of the resistance."

Having been caught into an exhausting political soap opera, the general public got confused, tired and eventually bored by the tents, camps, marches and street blockades that would not let them get to work/home. The "cliktivism" eventually became the main form of activism: the people preferred debating or even fighting through internet forums. ${ }^{6}$

\section{Instead of Conclusion: The Post-Protest Anti-Climax and Depression}

One year after the student protests that promised a "Macedonian Spring", the country is back on square one. The political parties have again occupied the public scene, and marginalized all other actors that for a while promised something new in the political realm. After the Ohrid Framework Agreement there is another internationally sponsored

${ }^{6} \mathrm{~A}$ witty aphorism read: We are neither VMRO-DPMNE nor SDSM, we are (from) Internet! 
framework agreement. The operationalization of the agreement goes in a non-transparent manner, within the close circles of four parties' representatives. The citizens are forgotten again, while the social movements face a dilemma: to stick to horizontal activism or to take part into the political game (elections in April 2016). It is additional crack in already disoriented protest movement.

A very important issue with regards to the protest movements in hybrid systems and weak states that are under the guide of the international state-builders is: is political spring as such desirable at all? Probably far more important issue is: is it possible? Some surveys (N. Markovic et al 2012, N. Markovikj and I. Damjanovski 2015) point out the obvious apathy and distrust in any organized form of political life such as parties, NGOs etc. The exciting currents of 2014/2015 are just an exciting episode that only proved that the protests per se cannot bring political (and even less societal) changes. At the end of the day many fingers point out at the citizens as the main culprits for the failure of what was supposed to be a Macedonian spring. Few consider the factors that systematically disempowered the citizens. Some researchers (Torpe L. and M. Ferrer-Fons 2007) argue that even in developed societies it has become more difficult to mobilize individuals around shared endeavours, at least with regard to long-term projects. If it is true that individuals are no longer potential full-time activists, but make independent choices on a case-by-case basis, than it is even truer for underdeveloped clientelistic societies. The organized protests tend to become opium of/for the masses: it makes some people feel better after expressing their frustrations but does not resolve the basic contradictions in the society based on firm neoliberal fundaments. The citizens have never been encouraged to take active participation that goes beyond party-politics; instead the political parties have always been the ones to mobilize (using stick and carrots), provide incentives and logistics for any mass rally. Actually, the greatest achievement of the student protests was precisely overcoming that distrust barrier with the majority citizens that are distrustful to political parties and NGOs in general.

\section{Bibliography}

1. Camson, William A (1990), The Strategy of Social Protest, 2nd ed. Belmont, CA:Wadsworth

2. Goldstone, Jack A. (ed.) (2003), States, Parties, and Social Movements, Cambridge: Cambridge University Press 
3. Habermas Jurgen (1998), "Three normative models of democracy". In J. Habermas (ed.), The inclusion of the other. Cambridge, MA: MIT Press

4. Habermas Jurgen (2006), "Political Communication in Media Society: Does Democracy Still Enjoy an Epistemic Dimension? The Impact of Normative Theory on Empirical Research", Communication Theory 16.

5. Hristova Lidija et al. (2011), "Politichkite identiteti vo Republika Makedonija", Skopje: ISPPI

6. Laclau, Ernesto (2005), On Populist Reason, London: Verso

7. Markovikj N. et al (2012), Politickata kultura vo Republika Makedonija, Skopje: Friedrich Ebert Stiftung \& IDSCS

8. Markovikj N. and I. Damjanovski (2015), "The uncharted political realm - social capital, political values and practices stimulating informal networks in Macedonia", New Balkan Politics, Issue 17.

9. Mouffe, Chantal (2015), "Transforming Political Consciousness", Green European Project, July, http://www.greeneuropeanjournal.eu/wpcontent/uploads/2015/09/ GEF-ED-2015-web.pdf

10. Puhovski, Zarko (2014), "Pobuna naroda protiv puka", Peščanik, 7 March, http://pescanik.net/pobuna-naroda-protiv-puka/

11. Ranciere Jacques(2015), "Sistem djeluje izazivajući osjećaj nemoći kod ljudi", Tačno. net, 16 October 2015, available at: http://www.tacno.net/interview/intervju-jacques-ranciere-filozof-sistemdjeluje-izazivajuci-osjecaj-nemoci-kod-ljudi/ (accessed on 20 October 2015)

12. Siljanovska-Davkova, Gordana (2005) "Organizational Structures and Inter Party Democracy in Macedonia" in ed. Georgi Karasimeonov (ed.), Organizational Structures and Internal Party Democracy in South Eastern Europe, Sofia: Coreex Press

13. Siljanovska-Davkova, Gordana (2014), "Internal Life of Political Parties in Western Balkans: Between Oligarchic Tendencies and Democratic Challenges", conference paper presented available at the IX World Congress "Constitutional Challenges: Global and Local", Oslo 16 - 20 June

14. Sisovski Jordan (2015), "David versus Goliath", http://zasedan.ie.mk/?p=1207

15. Tilly, Charles (1978), From Mobilization to Revolution. Reading, MA: AddisonWesley 


\section{Securilatity}

16. Vangeli Anastas (2015), "Pregovorite sto bolat", Fokus,

http://fokus.mk/pregovorite-shto-bolat/

17. Torpe L. and M. Ferrer-Fons (2007), "The internal structure of associations". In: W.A. Maloney and S. Rosteutscher (eds.), Social capital and associations in European democracies. A comparative analysis, (New York: Routledge, 2007): 97.

18. Vankovska, Biljana (2014), Politichki sistem na Republika Makedonija, Skopje: UKIM

19. Wagner, Peter (2012), Modernity, Cambridge: Polity Press 